\title{
TEKNOLOGI LUMPUR AKTIF DALAM PENGOLAHAN AIR LIMBAH PEMUKIMAN KARYAWAN DAN PERKANTORAN PT KALTIM PRIMA COAL
}

\author{
Kris Pranoto ${ }^{1}$, Widia Rahmawati Pahilda ${ }^{2}$, Muhammad Sonny Abfertiawan ${ }^{3}$, \\ Apridawati Elistyandari ${ }^{1}$, Andi Sutikno ${ }^{1}$ \\ ${ }^{1)}$ Environmental Department, Kaltim Prima Coal, \\ ${ }^{2)}$ PT. Ganeca Environmental Services, Indonesia, \\ ${ }^{3)}$ Kelompok Keahlian Rekayasa Air dan Limbah Cair, Fakultas Teknik Sipil dan Lingkungan, ITB
}

\begin{abstract}
ABSTRAK
Di Indonesia, operasional penambangan batubara umumnya melibatkan tenaga kerja dengan jumlah yang besar. Kondisi ini memberikan tantangan tersendiri dalam pengelolaan dampak lingkungan yang berpotensi timbul dari aktivitas manusia. Salah satu potensi tersebut yakni air limbah domestik. Air limbah domestik merupakan air limbah yang berasal dari aktivitas hidup sehari-hari manusia yang berhubungan dengan pemakaian air. Di area operasional pertambangan, air limbah domestik dapat timbul dari area pemukiman karyawan dan perkantoran. Karena potensi dampaknya terhadap lingkungan, air limbah domestik harus diolah sebelum dialirkan ke badan air penerima. Sejak tahun 1990an, diawal operasi penambangan, Kaltim Prima Coal (KPC) telah membangun dan mengoperasiokan Instalasi Pengolahan Air Limbah Domestik (IPALD) untuk mengolah air limbah domestik yang bersumber dari pemukiman karyawan dan perkantoran. Terdapat 12 IPALD dengan teknologi lumpur aktif yang beroperasi di area KPC. Lumpur aktif merupakan salah satu teknologi pengolahan air limbah domestik dengan memanfaatkan peran bakteri aerob untuk mendegradasi material organik yang terkandung didalam air limbah domestik. Makalah ini disajikan untuk mendeskripsikan performa teknologi lumpur aktif yang digunakan dalam IPALD KPC dan tantangan yang dihadapi dalam pengoperasiannya. Salah satu tantangan yang dihadapi yakni pemenuhan baku mutu yang tertuang dalam Keputusan Menteri Lingkungan Hidup dan Kehutanan No. P. 68 Tahun 2016 tentang Baku Mutu Air Limbah Domestik. Baku mutu terbaru mengatur konsentrasi efluen IPALD lebih ketat dari sebelumnya dan terdapat paramater baru, diantaranya amoniak yang memerlukan perhatian dalam pengoperasian IPALD.
\end{abstract}

Kata kunci: air limbah domestik, lumpur aktif, ipald

\section{ABSTRACT}

In Indonesia, coal mining operations generally involve a huge number of workers. This condition causes its own challenges in managing environmental impacts that potentially generated from human activities. One of them is domestic wastewater. Domestic waste water is waste water that comes from activities of daily living of humans related to water usage. In mining operations, domestic wastewater is generated from office and residential areas. Because of the potential impact on the environment, domestic wastewater must be treated before flowing to natural water bodies. Since the beginning of mining operations in 1990s, PT Kaltim Prima Coal has been building and operating Domestic Wastewater Treatment Plant (IPALD) to treat domestic wastewater resulting from offices and residential areas. There are 12 IPALDs with activated sludge technology operating in the KPC area. Active sludge is one of the domestic wastewater treatment technologies by utilizing the role of aerobic bacteria to degrade organic material contained in domestic wastewater. This paper is presented to 
describe the performance of activated sludge technology used in the KPC's IPALD and the challenges faced in its operation. One of the challenges faced is the fulfillment of water quality standards in Minister of Environment and Forestry Decree No. P. 68 of 2016 concerning Domestic Wastewater Quality Standards. The latest quality standards regulate the effluent concentration of IPALD more stringent than before and there are new parameters, including ammonia which requires attention in the operation of IPALD.

Keywords: domestic waste water, activated sludge, ipald

\section{A. PENDAHULUAN}

Industri pertambangan menjadi salah satu industri yang berpotensi memberikan multiplier effect terhadap kehidupan masyarakat, khususnya dalam aspek perekonomian. Di Indonesia cukup banyak daerah yang menjadikan sektor pertambangan sebagai sumber utama pendapatan daerah. Namun, selain potensi dampak positif tersebut, kegiatan pertambangan juga berpotensi menimbulkan dampak negatif terhadap lingkungan. Perusahaan industri pertambangan perlu melakukan langkah-langkah tepat untuk menerapkan kaidah penambangan yang baik (best mining practices) sehingga dapat menyeimbangkan antara kegiatan produksi dengan upaya perlindungan lingkungan. Hal ini juga diamanahkan di dalam Undang-undang RI No. 4 Tahun 2009 tentang Pertambangan Mineral Dan Batubara. Regulasi ini memberikan kewajiban kepada pemilik Izin Usaha Pertambangan (IUP) dan Izin Usaha Pertambangan Khusus (IUPK) untuk menerapkan kaidah teknik penambangan yang baik serta mematuhi batas toleransi daya dukung lingkungan (Pasal 95, a dan e).

PT Kaltim Prima Coal (KPC) merupakan salah satu perusahaan yang bergerak ada bidang pertambangan batubara yang berlokasi di Sangatta, Kabupaten Kutai Timur, Provinsi Kalimantan Timur. PT KPC memiliki luas area pertambangan sebesar 84.938 hektar serta memiliki jumlah karyawan sebanyak 4.500 dan 21.000 personel dari kontraktor. Banyaknya karyawan yang bekerja memberikan tantangan tersendiri dalam pengelolaan dampak lingkungan yang berpotensi timbul dari aktivitas manusia. Salah satunya yaitu bersumber dari air limbah domestik. Air limbah domestik merupakan air limbah yang timbul dari aktivitas hidup sehari-hari manusia yang berhubungan dengan pemakaian air. Pada area operasional air limbah domestik berasal dari perkantoran dan pemukiman karyawan yaitu untuk kegiatan mandi, cuci, kakus, dan dapur.

PT KPC saat ini memiliki 12 Instalasi Pengolahan Air Limbah Domestik (IPLD) yang melayani masing-masing fasilitas yang berbeda. IPALD yang terdapat pada area operasional tersebut telah dioperasikan sejak tahun 1990an menggunakan sistem lumpur aktif. Pada awal operasionalnya kualitas air hasil olahan (efluen) IPALD mengacu baku mutu air limbah domestik pada Peraturan Daerah Provinsi Kalimantan Timur Nomor 02 Tahun 2011 Tentang Pengelolaan Kualitas Air dan Pengendalian Pencemaran Air. Namun, regulasi terkait air limbah domestik saat ini harus mengacu pada regulasi baru yang telah dikeluarkan pemerintah pada Keputusan Menteri Lingkungan Hidup dan Kehutanan No. P. 68 Tahun 2016 tentang Baku Mutu Air Limbah Domestik. Pada regulasi baru ini nilai baku mutu untuk parameter Biochemical Oxygen Demand (BOD), Chemical Oxygen Demand (COD), dan Amonia lebih ketat dibandingkan regulasi yang digunakan sebelumnya.

Sebelumnya KPC telah melakukan studi evaluasi kinerja pengolahan air limbah domestik pada IPALD serta melakukan analisa laboratorium terhadap kualitas efluen IPALD dengan baku mutu pada Keputusan Menteri Lingkungan Hidup dan Kehutanan No. P. 68 Tahun 2016 tentang Baku Mutu Air 
Limbah Domestik. Makalah ini difokuskan untuk membahas mengenai teknologi lumpur aktif pada IPALD yang digunakan untuk pengolahan air limbah domestik di PT KPC.

\section{B. METODOLOGI PENELITIAN}

Studi dilakukan dengan mengumpulkan data primer dan sekunder terkait pengelolaan air limbah domestik sebagai berikut:

a. Data Primer: Dilakukan dengan menggunakan metode kuantitatif dan kualitatif. Data Kuantitaif dikumpulkan dengan pengambilan sampel dan analisis laboratorium sampel air limbah domestik

b. Data sekunder yang dikumpulkan meliputi: (1) kumpulan peraturan, perundang-undangan dan kebijakan; (2) informasi mengenai sumber air limbah domestik dan area layanan IPALD; dan (3) teknologi dan sistem pengolahan air limbah domestik pada IPALD.

\section{HASIL DAN PEMBAHASAN}

\section{C.1 Timbulan Air Limbah Domestik}

Timbulan air limbah domestik berhubungan dengan beban pengolahan pada IPALD, maka dilakukan perhitungan terhadap debit timbulan air limbah domestik dari setiap area pelayanan IPALD. Perhitungan debit timbulan air limbah domestik dilakukan dengan menggunakan pendekatan kebutuhan air bersih (meter kubik atau liter per orang per hari). Pada Tabel 1 dapat dilihat hasil peritungan timbulan air limbah yang masuk pada tiap-tiap IPALD dengan asumsi kebutuhan air bersih yang berbeda-beda sesuai fungsi bangunan di area pelayanan.

Tabel 1 Volume Influen Air Limbah Domestik PT KPC

\begin{tabular}{ccr}
\hline No & IPALD & \multicolumn{2}{c}{$\begin{array}{c}\text { Debit Air Limbah Domestik } \\
\left(\mathbf{m}^{\mathbf{3}} / \mathbf{h a r i}\right)\end{array}$} \\
\hline 1 & IPALD 1 & 209,664 \\
2 & IPALD 2 & 206,208 \\
3 & IPALD 3 & 215,424 \\
4 & IPALD 3A & 86,4 \\
5 & IPALD 4 & 56,64 \\
6 & IPALD 5 & 109,52 \\
7 & IPALD 6 & 85,536 \\
8 & IPALD 7 & 4,24 \\
9 & IPALD 8 & 17,984 \\
10 & IPALD 9 & 77,04 \\
11 & IPALD 10 & 387,616 \\
12 & IPALD 11 & 221,184 \\
\hline
\end{tabular}

\section{C.2 Kualitas Influen}

Nilai $\mathrm{pH}$ influen pada IPALD berada pada rentang 6,59-7,22 sehingga tidak mengganggu proses biologi yang digunakan di IPALD. Pada air limbah domestik, secara umum cukup jarang ditemukan pada $\mathrm{pH}$ yang sangat rendah atau sangat basa. Umumnya, air limbah domestik masih berada pada kisaran $\mathrm{pH}$ 6-8. Pada proses biologi $\mathrm{pH}$ optimum untuk mendukung terjadinya proses nitrifikasi yaitu pada kisaran 7,5 - 8,5 (Gerardi, 1994). Pada pH 6,3 - 6,7 laju nitrifikasi akan mulai menurun dan akan berhenti pada pH 5-5,5 (Sopiah, 2006). 
Untuk parameter BOD pada influent IPALD secara umum berada pada rentang konsentrasi 48-172 $\mathrm{mg} / \mathrm{L}$. Kadar BOD yang tinggi melebih baku mutu seperti pada hasil pemeriksaan Laboratorium diatas disebabkan karena tingginya kandungan bahan-bahan organik pada air limbah domestik. BOD merupakan oksigen yang dibutuhkan oleh bakteri untuk menguraikan zat organik menjadi karbondioksida dan Amonia $\left(\mathrm{NH}_{3}\right)$ (Syakur, dkk., 2017). Sedangkan parameter COD pada influen IPALD berada pada rentang 125-1192 mg/L. COD adalah jumlah oksigen yang dibutuhkan oleh mikroorganisme untuk menguraikan zat organik secara kimiawi (Islam B, dkk., 2014). Besarnya perbandingan BOD dan COD akan menunjukkan jumlah zat organik yang dapat diuraikan secara biologis (Soedjono, 2018). Jika harga perbandingan BOD dan COD semakin kecil maka jumlah zat organik yang dapat diuraikan secara biologis yang terdapat dalam air buangan juga semakin kecil.

Kandungan Amoniak pada influen IPALD berada pada rentang 4,89-24,38 mg/L. Tingginya kadar amonia merupakan ciri khas dari air limbah domestik. Hal ini disebabkan senyawa amonia merupakan produk utama dari penguraian limbah yang mengandung senyawa nitrogen seperti pada urine dan feses yang masuk ke dalam sistem pengolahan air limbah . Pertumbuhan bakteri untuk proses nitrifikasi pada proses biologi dapat terhambat apabila amonia berada pada konsentrasi lebih besar dari $750 \mathrm{mg} / \mathrm{l}$ (Barness, 1983)

Parameter minyak dan lemak pada influen IPALD berkisar antara 1-12 mg/L. Minyak dan lemak ini membentuk lapisan tipis di permukaan air karena seperti yang kita ketahui berat jenis minyak lebih kecil dibandingkan berat jenis air. Adapun kualitas influent dari masing-masing IPALD dapat dilihat pada Tabel 2.

Tabel 2 Kualitas Influent Masing-masing IPALD

\begin{tabular}{|c|c|c|c|c|c|c|c|}
\hline \multirow[b]{2}{*}{ IPALD } & \multicolumn{7}{|c|}{ Parameter } \\
\hline & pH & BOD & COD & TSS & $\begin{array}{c}\text { Minyak } \\
\text { dan } \\
\text { Lemak }\end{array}$ & Amoniak & E. Coli \\
\hline IPALD 1 & 6,59 & 169 & 1192 & 326 & 15 & 24,28 & $>20 \times 10^{3}$ \\
\hline IPALD 2 & 6,68 & 172 & 877 & 565 & 12 & 24,38 & $>20 \times 10^{3}$ \\
\hline IPALD 3 & 7,22 & 123 & 288 & 244 & 5 & 24,48 & $>20 \times 10^{3}$ \\
\hline IPALD 3A & - & - & - & - & - & - & - \\
\hline IPALD 4 & 6,99 & 107 & 125 & 104 & 3 & 16,12 & $>20 . \times 10^{3}$ \\
\hline IPALD 5 & - & - & - & - & - & - & - \\
\hline IPALD 6 & 7,14 & 48 & 125 & 76 & 3 & 16,86 & $>20 \times 10^{3}$ \\
\hline IPALD 7 & - & - & - & - & - & - & - \\
\hline IPALD 8 & 6,57 & 62 & 279 & 114 & 9 & 6,37 & $>20 \times 10^{3}$ \\
\hline IPALD 9 & - & - & - & - & - & - & - \\
\hline IPALD 10 & 6,78 & 91 & 1000 & 1005 & 3 & 4,89 & $>20 \times 10^{3}$ \\
\hline IPALD 11 & 6,73 & 98 & 337 & 295 & 1 & 12,77 & $>20 \times 10^{3}$ \\
\hline
\end{tabular}

\section{C.3 Pengolahan Air Limbah Domestik}

Semua IPALD yang dimiliki dan dioperasikan oleh PT KPC dirancang dengan menggunakan metode pengolahan biologi. Sebelum dipompakan menuju IPALD air limbah dari tiap fasilitas dikumpulkan terlebih dahulu pada unit pengumpul pertama. Unit pengumpul pertama berfungsi untuk menyeragamkan kualitas dan kuantitas air limbah sebelum dialirkan ke unit pengolahan selanjutnya. 
Dengan seragamnya kualitas dan kuantitas air limbah diharapkan performa pengolahan khususnya pengolahan biologi dapat berjalan secara baik dan terhindar dari potensi shock loading.

Air limbah domestik kemudian dialirkan melalui jaringan perpipaan secara gravitasi maupun aliran bertekanan (pemompaan) menuju ke inlet IPALD Pada inlet terdapat screen yang berfungsi sebagai penyaring dari course material seperti sampah. Selanjutnya, air limbah domestik langsung masuk ke tangki aerasi. Didalam tangki ini, air limbah akan diaduk dengan menggunakan aerator udara sekaligus untuk memenuhi kebutuhan oksigen bagi mikroorganisme sebagai bagian dari proses degradasi material organik karbon yang terkandung didalam air limbah domestik. Proses biologi didalam tangki aerasi atau juga dapat disebut sebagai proses lumpur aktif (activated sludge) akan menghasilkan bioflock atau sel baru yang mudah untuk diendapkan. Air limbah domestik dari tangki aerasi akan dialirkan menuju ke tangki sedimentasi untuk mengendapkan bio-flock yang telah terbentuk didalam tangki aerasi. Pengendalam berlangsung secara gravitasi. Bio-flock yang memiliki massa lebih berat akan terendapkan kedalam dasar tangki atau ruang lumpur sedangkan air bersih akan mengalir keluar melalui pelimpah (weir) menuju ke pengolahan selanjutnya. Lumpur yang telah mengendap didasar tangki sedimentasi atau clarifier akan dipompa keluar menuju digester.

Digester merupakan tangki untuk proses digesting atau pematangan lumpur. Unit pengolahan lumpur ini dirancang untuk membunuh material organik yang masih cukup tinggi didalam lumpur. Dalam beberapa kasus, pengolahan lumpur melalui unit pengolahan digester penting untuk dilakukan agar material organik dan bakteri patogen yang terkandung didalam lumpur dapat disisihkan secara aerob maupun anaerob sehingga aman untuk dilepas ke lingkungan.

Selain itu, lumpur yang telah diendapkan di tangki sedimentasi akan dialirkan sebagian ke tangki aerasi kembali sebagai lumpur resirkulasi. Proses ini merupakan bagian penting dalam sistem lumpur aktif. Lumpur yang kaya dengan kandungan mikroorganisme akan berguna dalam mempertahankan proses biologi yang optimal di tangki aerasi. Sebagian lumpur lainnya akan dibuang.

Efluen atau overflow dari tangki pengendapan atau clarifier selanjutnya mengalir ke tangki aerasi lanjutan. Tangki aerasi lanjutan (Extended Aeration) ini dibangun untuk mendegradasi amoniak yang masih ditemukan dengan konsentrasi yang relatif tinggi pada efluen clarifier. Proses nitrifikasi ini dilakukan pada kolam yang disuplai dengan pompa udara. Efluen dari tangki aerasi lanjutan ini diharapkan dapat memiliki kualitas dengan konsentrasi amoniak yang sudah memenuhi baku mutu lingkungan yang berlaku. Sebelum dialirkan keluar menuju badan air penerima, air limbah dibubuhkan desinfektan untuk membuh mikroorganisme yang berbahaya yang berpotensi masih terkandung didalam efluen. Skematik umum IPALD yang beroperasi di area PT KPC dapat dilihat pada Gambar 1.

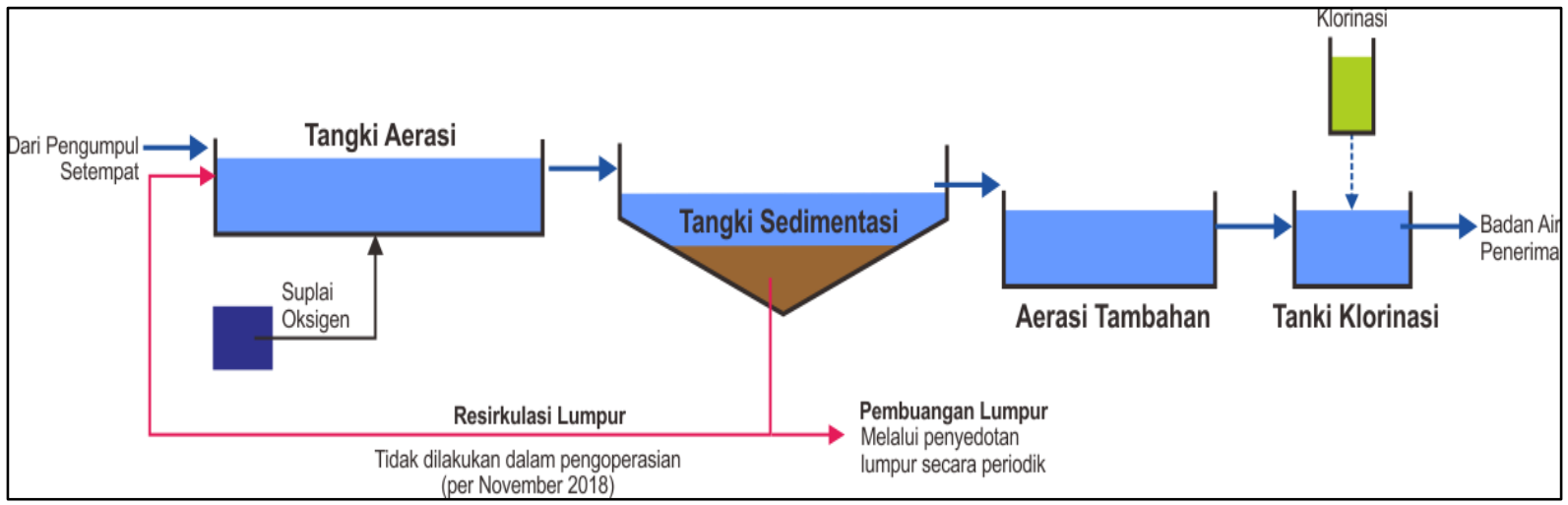

Gambar 1 Alur Pengolahan IPALD PT KPC 
Pada pengolahan biologi menggunakan sistem aerasi kebutuhan oksigen sangat penting untuk diperhatikan karena berpengaruh secara langsung terhadap pertumbuhan bakteri yang akan mendegradasi organik karbon yang terkandung didalam air limbah. Selain itu, ketersedian oksigen dibutuhkan untuk proses nitrifikasi yaitu proses degradasi Amonium $\left(\mathrm{NH}_{3}\right)$ menjadi menjadi nitrat $\left(\mathrm{NO}_{3}\right)$ (Widayat, dkk., 2010). Konsentrasi oksigen terlarut atau Dissolved Oxygen (DO) minimal untuk proses nitrifikasi yaitu sebesar $2 \mathrm{mg} / \mathrm{L}$ (Nainggolan, dkk., 2015). Kebutuhan oksigen dapat dipenuhi dengan memberikan suplai udara kedalam air. Untuk mengetahui kebutuhan suplai udara (volume udara), dibutuhkan jumlah kebutuhan oksigen. Unit aerasi dapat menurunkan konsentrasi BOD sebesar 75\%-95\% (Siregar, 2005).

\section{C.4. Kualitas Pengolahan IPALD}

Baku mutu efluen dari masing-masing IPALD mengacu pada baku mutu yang disyaratkan pada PermenLHK Nomor 68 Tahun 2016 Tentang Baku Mutu Air Limbah Domestik. Dalam baku mutu ini tiap parameter efluen air limbah lebih ketat dibandingkan dengan baku mutu pada Peraturan Daerah Provinsi Kalimantan Timur Nomor 02 Tahun 2011 tentang Pengelolaan Kualitas Air dan Pengendalian Pencemaran Air Untuk Air Limbah Domestik, yang sebelumnya menjadi acuan baku mutu efluen limbah domestik di PT Kaltim Prima Coal. PT KPC secara rutin melakukan analisa laboratorium untuk mengetahui kualitas efluen air limbah domestik. Pada Tabel 3 dapat dilihat kualitas efluen air limbah domestik pada periode pengujian Mei 2019. Hasil analisa laboratorium menunjukkan bahwa hasil olahan air limbah domestik pada seluruh IPALD PT KPC telah memenuhi persyaratan baku mutu.

Tabel 3 Kualitas Efluen Air Limbah Domestik PT KPC Periode Mei 2019

\begin{tabular}{|c|c|c|c|c|c|c|c|}
\hline \multirow[b]{2}{*}{ IPALD } & \multicolumn{7}{|c|}{ Parameter } \\
\hline & $\begin{array}{c}\text { BOD } \\
(\mathrm{mg} / \mathrm{L}) \\
\end{array}$ & $\begin{array}{r}\text { COD } \\
(\mathrm{mg} / \mathrm{L}) \\
\end{array}$ & $\begin{array}{c}\text { TSS } \\
(\mathrm{mg} / \mathrm{L}) \\
\end{array}$ & $\begin{array}{c}\text { Minyak \& } \\
\text { Lemak } \\
(\mathrm{mg} / \mathrm{L}) \\
\end{array}$ & $\begin{array}{l}\text { Amonia } \\
(\mathrm{mg} / \mathrm{L}) \\
\end{array}$ & $\begin{array}{c}\text { pH } \\
- \\
\end{array}$ & $\begin{array}{l}\text { Total Coliform } \\
\text { MPN/100 mL } \\
\end{array}$ \\
\hline Baku Mutu*) & 30 & 100 & 30 & 5 & 10 & $6-9$ & 3.000 \\
\hline IPALD 1 dan $10^{* *}$ ) & 20 & 49 & 9 & 0,01 & 0,41 & 6,78 & 0 \\
\hline IPALD 2 & 23 & 45 & 3 & 0,01 & 0,4 & 6,21 & 0 \\
\hline IPALD 3 dan $\left.3 \mathrm{~A}^{* *}\right)$ & 28 & 61 & 7 & 0,01 & 0,24 & 6,84 & 0 \\
\hline IPALD 4 & 19 & 39 & 1 & 0,01 & 0,09 & 7,24 & 0 \\
\hline IPALD 5 & 28 & 55 & 5 & 0,01 & 0,02 & 8,7 & 0 \\
\hline IPALD 6 & 17 & 42 & 10 & 0,01 & 0,14 & 6,4 & 0 \\
\hline IPALD 7 & 21 & 49 & 1 & 0,01 & 1,25 & 7,31 & 0 \\
\hline IPALD 8 & 22 & 52 & 6 & 0,01 & 0,05 & 7,7 & 0 \\
\hline IPALD 9 & 28 & 68 & 8 & 0,01 & 2,17 & 7,65 & 0 \\
\hline IPALD 11 & 26 & 55 & 5 & 0,01 & 0,77 & 6,35 & 24,4 \\
\hline
\end{tabular}

Keterangan:

*) PermenLHK Nomor 68 Tahun 2016 Tentang Baku Mutu Air Limbah Domestik

**) Efluen IPALD 1 dan IPALD 10 serta IPALD 3 dan 3 A ini dialirkan ke satu titik yang sama dikarenakan lokasi dari kedua IPALD ini berada di satu lokasi

\section{SIMPULAN}

Secara umum teknologi pengolahan air limbah domestik yang digunakan PT KPC saat ini telah berjalan dengan baik dalam melakukan pengolahan air limbah domestik. Penerapan teknologi 
pengolahan menggunakan sistem biologi merupakan teknologi yang tepat dalam menyisihkan kandungan pecemar air limbah domestik yang didominasi oleh kandungan organik. Akan tetapi, suplai oksigen pada unit pengolahan biologi (tangki aerasi) harus diperhatikan agar tetap berada pada kadar minimum oksigen untuk penyisihan material organik (BOD, COD, dan Amonia) pada air limbah domestik.

\section{DAFTAR PUSTAKA}

Barness, D. and Bliss, P.J., 1983, Biological Control of Nitrogen in Wastewater Treatment. E \& F.N Spon Ltd.,New York.

Bita Enarcon Engineering, 2007, Evaluation Study of Sewer Treatment Plant (STP) in Swarga Bara and Tanjung Bara Area

Ganeca Environmental Services, 2019, Performance Assesment of Domestic Waste Water Treatment Plant at PT KPC Site, Indonesia.

Gerardi, Michael H. 1994. Wastewater Biology: The Life Process. Water Environment Federation, USA.

Islam B, Musa a, Ibrahim E, Sharafa S, Elfaki B. 2014. Evaluation and Characterization of Tannery Wastewater. J For Prod Ind [Internet]. 2014 3(3) pp 141-50.

Keputusan Menteri Lingkungan Hidup dan Kehutanan No. P. 68 Tahun 2016 tentang Baku Mutu Air Limbah Domestik.

Nainggolan, Afrianti, Tetty. Khotimah, Siti. Turnip, Masnur. 2015. Bakteri Pendegradasi Amonia Limbah Cair Karet Pontianak Kalimantan Barat. Protobiont (2015) Vol. 4 (2) : 69-76

Said, Nusa I,, 2008, Teknologi Pengolahan Air Minum, Teori dan Pengalaman Praktis

Peraturan Daerah Kalimantan Timur No. 02 tahun 2011 Tentang Pengelolaan Kualitas Air dan Pengendalian Pencemaran Air.

Siregar, Sakti A. (2005). Instalasi Pengolahan Air Limbah: Kanisius. Yogyakarta. ISBN 99-21-0840-8

Soedjono, Wijaya. 2018. Physicochemical Characteristic of Municipal Wastewater in Tropical Area: Case Study of Surabaya City, Indonesia. IOP Conf. Series: Earth and Environmental Science 135 (2018) 012018 doi :10.1088/1755-1315/135/1/01201

Sopiah, Nida. Titiresmi. 2006. Teknologi Biofilter Untuk Pengolahan Limbah Amonia. Balai Teknologi Lingkungan (BPPT). J. Tek. Ling Vol 7 No 2 Hal. 173-179.

Syakur, abdul. Zaman, Badrus, Nurmaliakasih, Dias, Yunita. 2017. Statistical Analysis of Reducing Biochemical Oxygen Demand (BOD) on Industrial Rubber Wastewater using Dielectric Barrier Discharge Plasma. IAES International Conference on Electrical Engineering, Computer Science and Informatics. IOP Conf. Series: Materials Science and Engineering 1234567890190 (2017) 012026 doi:10.1088/1757-899X/190/1/012026

Widayat, Wahyu, Surihatin, Herlambang, arie. 2010. Penyisihan Amoniak Dalam Upaya Meningkatkan Kualitas Air Baku PDAM-Ipa Bojong Renged Dengan Proses Biofiltrasi Menggunakan Media Plastik Tipe Sarang Tawon. JAI Vol 6. No. 1. 2010, 64-76 
PROSIDING TPT XXVIII PERHAPI 2019 